\title{
Effects of fluoride on the removal of cadmium and phosphate by aluminum coagulation
}

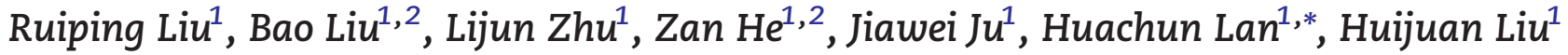 \\ 1. Key Laboratory of Drinking Water Science and Technology, Research Center for Eco-Environmental Sciences, Chinese Academy of Sciences, \\ Beijing 100085, China \\ 2. University of Chinese Academy of Sciences, Beijing 100039, China
}

\section{A R T I C L E I N F O}

Article history:

Received 4 August 2014

Revised 21 October 2014

Accepted 24 October 2014

Available online 22 April 2015

Keywords:

Fluoride

Aluminum coagulation

Al-F complexes

$\zeta$-Potential

Adsorbent reclamation

\begin{abstract}
A B S T R A C T
This study focuses on the effects of $\mathrm{pH}$ and fluoride at different molar ratios of fluoride to $\mathrm{Al}$ $\left(R_{F: A l}\right)$ on the removal of cadmium $\left(\mathrm{Cd}^{2+}\right)$ and phosphate by $\mathrm{Al}$ coagulation. Fluoride at $R_{\mathrm{F}: \mathrm{Al}} \geq 3: 1$ inhibits the removal of Cd over wide Al dose ranges from 5 to $10 \mathrm{mg} / \mathrm{L}$ as Al. The removal of phosphate decreases significantly at high $R_{\mathrm{F}: A l}$ of 10:1 whereas at lowered $R_{\mathrm{F}: A l}$ (i.e., $\leq 6: 1$ ), an adverse effect is observed only at insufficient $\mathrm{Al}$ doses below $2 \mathrm{mg} / \mathrm{L}$. Fluoride shows inhibitive effects towards the removal of $\mathrm{Cd}$ at $\mathrm{pH} 7$ and 8 and that of phosphate at $\mathrm{pH}$ 6. Fluoride decreases the $\zeta$-potential in both systems, and the decreasing extent is positively correlated to the elevated $R_{\mathrm{F}: \mathrm{Al}}$. The Al fluoride interactions include the formation of Al-F complexes and the adsorption of fluoride onto $\mathrm{Al}(\mathrm{OH})_{3}$ precipitates, i.e., the formation of $\mathrm{Al}(\mathrm{OH})_{n} \mathrm{~F}_{m}$. Al-F complex formation inhibits $\mathrm{Al}$ hydrolysis and increases residual Al levels, and a more significant increase was observed at lower $\mathrm{pH}$. Al-F complexes at high $R_{\mathrm{F}: \mathrm{Al}}$ complicate the coagulation behavior of $\mathrm{Al}$ towards both negative and positive ionic species. Moreover, fluoride at low $R_{\mathrm{F}: \mathrm{Al}}$ shows little effect on $\mathrm{Al}$ coagulation behavior towards $\mathrm{Cd}^{2+}$ and phosphate, and the spent defluoridation adsorbent, i.e., aluminum (Al) hydro(oxide) with adsorbed fluoride at $R_{\mathrm{F}: \mathrm{Al}}$ of below 0.1:1, may be reclaimed as a coagulant after being dissolved.
\end{abstract}

(C) 2015 The Research Center for Eco-Environmental Sciences, Chinese Academy of Sciences. Published by Elsevier B.V.

\section{Introduction}

Some industries, e.g., semiconductor production, tantalum and niobium refinery, and rare earth refinery, produce complicated wastewaters with fluoride concentrations from several to several tens of thousand $\mathrm{mg} / \mathrm{L}$, and soluble species such as heavy metals, phosphate, and arsenic are sometimes simultaneously present (Wen and Du, 2001; Zhu et al., 2005; Zhang et al., 2006). The simultaneous removal of these pollutants has practical value from an engineering point-ofview. Coagulation and/or electro-coagulation are feasible ways to remove the positively-charged heavy metals and negative anions such as phosphate, arsenic, and fluoride (Aguilar et al., 2002; Meng et al., 2000; Merzouk et al., 2009; Akbal and Camcl, 2010; Gong et al., 2012). Coagulation by aluminum (Al) salts shows promise to achieve their simultaneous removal due to the good affinity of Al hydro (oxide) towards them. By comparison, iron salts exhibit little efficacy for the removal of fluoride, although they show strong affinity towards arsenic and phosphate.

Although the removal of fluoride by Al-based (electro)coagulation has been studied (Gong et al., 2012; Zhao et al., 2009; Bhatnagar et al., 2011), studies investigating the effects of fluoride on the removal of abovementioned ions are rare.

\footnotetext{
* Corresponding author. E-mail: hclan@rcees.ac.cn (Huachun Lan).
} 
Aluminum-fluoride interactions dominate in the species distribution, transport and toxicity of aluminum. In acidic deposition areas, the formation of aluminum fluoride complexes (Al-F complexes) was reported to be extremely important in the transport of elemental aluminum and its toxicity towards fish in surface waters (Driscoll et al., 1980; Radic and Bralic, 1995). The rate of aluminum fluoride complexation is observed to be highly dependent on $\mathrm{pH}$ (Neal, 1995), and the formation of hydrolyzed $\mathrm{Al}(\mathrm{III})$ species (i.e., $\mathrm{Al}\left(\mathrm{H}_{2} \mathrm{O}\right)_{5}(\mathrm{OH})^{2+}$ ) at $\mathrm{pH}$ above 4.5 significantly increases the complexation rate (Plankey et al., 1988). As indicated by potentiometric study and thermodynamic modeling, the Al-F complexes' speciation is rather complicated and their species distribution is highly dependent on $\mathrm{pH}$, fluoride concentrations, and ionic strength (Corbillon et al., 2008). The ratios of complexed fluoride to total fluoride were observed to be strongly dependent on solution $\mathrm{pH}$ and the molar ratios of $\mathrm{F}$ to $\mathrm{Al}\left(\mathrm{R}_{\mathrm{F}: \mathrm{Al}}\right)$ (Gong et al., 2012). The effects of aluminum-fluoride interactions on the coagulation behaviors of $\mathrm{Al}$ salts should be carefully evaluated. Al-F complex formation affects the hydrolysis of $\mathrm{Al}^{3+}$ and the formation of $\mathrm{Al}(\mathrm{OH})_{3}$ precipitates, and presumably inhibits the removal of negatively-charged anions such as arsenate and phosphate. Our previous study indicated the adverse effect of fluoride on aluminum coagulation in kaolin suspensions, and the formation of Al-F complexes at high fluoride levels dominated in its inhibitive effect (Liu et al., 2013). Besides Al-F complex formation, the adsorption of fluoride onto Al hydro (oxide) also plays a role. Pommerenk and Schafran (2005) indicated that the attachment of fluoride on hydrous aluminum oxide decreased its surface charge and adversely affected the removal of natural organic matter (NOM) accordingly (Pommerenk and Schafran, 2005). Furthermore, aluminum oxide tends to dissolve in the acidic $\mathrm{pH}$ range. The dissolution may be enhanced after it is dosed into fluoride-containing water, and the removal of other species might be inhibited thereafter. However, the effect of fluoride on the removal of coexisting ions by $\mathrm{Al}$ coagulation is far from being well characterized to the best of our knowledge.

On the other hand, the wide occurrence of fluorosis has received great concern globally (Fawell et al., 2006). Although various techniques have been proposed for defluoridation (Bhatnagar et al., 2011; Fawell et al., 2006; Mohapatra et al., 2009), their implementation has been restricted by high cost, labor-intensive maintenance, and/or low ratios of water production (Mohapatra et al., 2009). The control of cost is of crucial importance (Fawell et al., 2006; Mohapatra et al., 2009), and the reclamation of spent adsorbents is economically valuable. This may be feasible considering the low equilibrium adsorption capacity $\left(Q_{e q}\right)$ towards fluoride for most adsorbents (Bhatnagar et al., 2011; Liu et al., 2011). The spent aluminum hydroxide, with adsorbed fluoride, may be reused as a coagulant to remove particulate colloids after being dissolved by acid solution (Liu et al., 2013). However, the feasibility of its reclamation for the removal of soluble ions such as cadmium $\left(\mathrm{Cd}^{2+}\right)$ and phosphate should be properly evaluated.

On the basis of these considerations, this study aims to: (1) investigate the effects of fluoride at different $R_{\mathrm{F}: \mathrm{Al}}$ ratios on the removal of positive $\mathrm{Cd}^{2+}$ and negative phosphate by $\mathrm{Al}$ coagulation over a wide $\mathrm{pH}$ range; (2) determine the effects of fluoride on the variation of residual Al levels and $\zeta$-potential involved in Al coagulation; and (3) propose the dominant species interactions between aluminum and fluoride over wide $\mathrm{pH}$ and $\mathrm{R}_{\mathrm{F}: \mathrm{Al}}$ ranges. Besides bench-scale experiments, the MINTEQ software was used to illustrate the interactions between $\mathrm{Al}^{3+}, \mathrm{Cd}^{2+}, \mathrm{F}^{-}$, and phosphate over a wide $\mathrm{pH}$ range.

\section{Materials and methods}

\subsection{Reagents and materials}

Unless otherwise noted, all chemicals were of analyticalreagent grade and were used without further purification. Stock solutions of $\mathrm{Al}^{3+}, \mathrm{F}^{-}, \mathrm{Cd}^{2+}$, and phosphate were prepared by dissolving aluminum chloride $\left(\mathrm{AlCl}_{3}\right)$, sodium fluoride $(\mathrm{NaF})$, cadmium nitrate $\left(\mathrm{Cd}\left(\mathrm{NO}_{3}\right)_{2}\right)$, and potassium phosphate $\left(\mathrm{KH}_{2} \mathrm{PO}_{4}\right)$ into deionized water, respectively. The NaF solution was kept in a polyethylene vessel.

Prior to being dosed, the stock solution of $\mathrm{Al}^{3+}$ and $\mathrm{F}^{-}$at different $R_{F: A l}$ was well mixed. This procedure was adopted considering that upon acidification of the spent $\mathrm{Al}_{2} \mathrm{O}_{3} \cdot \mathrm{xH}_{2} \mathrm{O}$ with adsorbed fluoride for its reclamation, a mixed solution of $\mathrm{Al}^{3+}$ and $\mathrm{F}^{-}$was obtained. Additionally, other contaminants may coexist in underground waters and can be adsorbed onto the spent $\mathrm{Al}_{2} \mathrm{O}_{3} \cdot \mathrm{xH}_{2} \mathrm{O}$; however, their interfering effects can be assumed to be slight and were ignored in this study. The equilibrium $\mathrm{pH}$ values and the ratios of complexed fluoride (the analysis methods are described in Section 1.3) in the mixed solutions at different $\mathrm{R}_{\mathrm{F}: \mathrm{Al}}$ ratios are illustrated in Fig. S1.

Raw water was respectively prepared by dosing stock solutions of $\mathrm{Cd}^{2+}$ or phosphate in tap water to desired concentrations of $3 \mathrm{mg} / \mathrm{L}$ as $\mathrm{Cd}$ and $2 \mathrm{mg} / \mathrm{L}$ as $\mathrm{P}$. The characteristics of the tap water are illustrated in Table S1. In $\mathrm{pH}$-effect experiments, solution $\mathrm{pH}$ was adjusted to the desired values with hydrochloric acid ( $\mathrm{HCl}$ ) and sodium hydroxide $(\mathrm{NaOH})$. The species distribution of $\mathrm{Cd}$ and phosphate over wide $\mathrm{pH}$ ranges from 4 to 10 , as calculated by the Visual MINTEQ software (see Section 1.4), is illustrated in Fig. S2. $\mathrm{Cd}^{2+}$ is the dominant species in the $\mathrm{pH}$ range from 4 to 9 , and the ratios of $\mathrm{Cd}^{2+}$ to total $\mathrm{Cd}$ decrease from $100 \%$ at $\mathrm{pH} 4$ to $92.4 \%$ at $\mathrm{pH} 9 . \mathrm{H}_{2} \mathrm{PO}_{4}^{-}$and $\mathrm{HPO}_{4}^{2-}$ are the main species at $\mathrm{pH}$ from 4 to 9 , and at $\mathrm{pH}$ above 7.2 the ratio of $\mathrm{HPO}_{4}^{2-}$ is over $50.6 \%$.

\subsection{Experimental methods}

Jar tests were performed using a Phipps and Bird six-paddle stirrer. Soon after a 10 -s rapid mixing period (250 r/min), the mixed solution of $\mathrm{AlCl}_{3}$ and $\mathrm{NaF}$ was added. After that, the coagulation procedures consisted of a 2-min rapid mix (200 r/min), 15-min slow mix (40 rpm), and a 30-min settling period. Samples for zeta potential ( $\zeta$-potential) analysis were sampled soon after the 10 -s rapid mixing period, whereas $\mathrm{pH}$ adjustment was carried out in the 2-min rapid mixing period when necessary. After 30-min settling, supernatants were collected and then filtered through $0.45-\mu \mathrm{m}$ membrane filters for further analysis. 


\subsection{Analysis methods}

$\zeta$-Potential was determined with a Zetasizer 2000 zeta potential analyzer (Malvern Co., Malvern Town, U.K.) and solution $\mathrm{pH}$ was analyzed with a Orion 720A pH meter (ThermoFisher Co., Waltham, Massachusetts, USA). The concentrations of $\mathrm{Al}, \mathrm{Cd}$, and phosphate as $\mathrm{P}$ were determined using an OPTIMA 2000DV Inductively Coupled Plasma Optical Emission Spectrometer (ICP-OES) (PerkinElmer Co., Waltham, Massachusetts, USA). The quantity of insoluble Al precipitates as $\mathrm{Al}$ was determined by subtracting the residual $\mathrm{Al}$ concentrations from the initial $\mathrm{Al}$ doses.

The concentrations of fluoride (free fluoride and total fluoride) were determined by the ion selective electrode method (PF-1, Shanghai KangYi Technology). The concentrations of complexed fluoride were determined by subtracting the concentration of free fluoride from that of total fluoride, according to the methods proposed in our previous study (Gong et al., 2012). Briefly, the abovementioned method was used except that a citrate buffer solution was added prior to the analysis of total fluoride concentrations.

\subsection{Modeling methods}

The visual MINTEQ software (Version 3.0, beta) was used to illustrate the species distribution of $\mathrm{Cd}$ and phosphate over wide $\mathrm{pH}$ ranges as well as the interactions between $\mathrm{Cd}, \mathrm{Al}$, fluoride, and phosphate. The concentrations of these elements were set according to the actual concentrations used in this study, and $\mathrm{pH}$ ranged from 4 to 10 . In the $\mathrm{Al}-\mathrm{F}$ system, the species $\mathrm{Al}^{3+}, \mathrm{F}^{-}, \mathrm{Al}(\mathrm{OH})^{2+}$, $\mathrm{Al}(\mathrm{OH})_{3}(\mathrm{aq}), \mathrm{Al}(\mathrm{OH})_{4}^{-}, \mathrm{AlF}^{2+}, \mathrm{AlF}_{2}^{+}, \mathrm{AlF}_{3}(\mathrm{aq}), \mathrm{AlOH}^{2+}, \mathrm{HF}(\mathrm{aq}), \mathrm{HF}_{2}^{-}, \mathrm{AlF}_{4}^{-}$, and $\mathrm{Al}_{2}(\mathrm{OH})_{2}^{4+}$ were included, and the four Al-F complexes of $\mathrm{AlF}^{2-}$, $\mathrm{AlF}_{2}^{-}, \mathrm{AlF}_{3}$, and $\mathrm{AlF}_{4}^{-}$were related to both the complexed fluoride and the complexed $\mathrm{Al}$. In the $\mathrm{Cd}-\mathrm{F}$ system, the $\mathrm{Cd}$ species $\mathrm{Cd}(\mathrm{OH})_{2}(\mathrm{aq})$, $\mathrm{Cd}(\mathrm{OH})_{3}^{-}, \mathrm{Cd}(\mathrm{OH})_{4}^{2-}, \mathrm{Cd}^{2+}, \mathrm{Cd}_{2} \mathrm{OH}^{3+}, \mathrm{CdF}^{+}$, and $\mathrm{CdOH}^{+}$were included, and $\mathrm{CdF}^{+}$was related to the $\mathrm{Cd}-\mathrm{F}$ complexes. In the Al-phosphate system, the $\mathrm{Al}$ species $\mathrm{Al}(\mathrm{OH})_{2}^{+}, \mathrm{Al}(\mathrm{OH})_{3}(\mathrm{aq}), \mathrm{Al}(\mathrm{OH})_{4}^{-}, \mathrm{Al}^{3+}, \mathrm{Al}_{2}(\mathrm{OH})_{2}^{4+}$, $\mathrm{Al}_{2} \mathrm{PO}_{4}^{3+}, \mathrm{Al}_{3}(\mathrm{OH})_{4}^{5+}, \mathrm{AlHPO}_{4}^{+}$, and $\mathrm{AlOH}^{2+}$ were included. The concentrations of $\mathrm{Cd}$, phosphate, $\mathrm{Al}$, and $\mathrm{F}$ in modeling were equal to those used in bench-scale experiments.

\section{Results and discussion}

\subsection{Effects of fluoride on the removal of $\mathrm{Cd}$ and phosphate at different $\mathrm{Al}$ doses}

Fig. 1 illustrates the effects of fluoride at $R_{\mathrm{F}: \mathrm{Al}}$ values from 0:1 to 10:1 on the removal of $\mathrm{Cd}$ and phosphate by $\mathrm{Al}$ coagulation with elevated $\mathrm{Al}$ doses. In the absence of fluoride $\left(R_{\mathrm{F}: \mathrm{Al}}=0: 1\right), \mathrm{Al}$ coagulation showed only slight efficiency in removing $\mathrm{Cd}$, and residual Cd was as high as $1.54 \mathrm{mg} / \mathrm{L}$ even at the high $\mathrm{Al}$ dose of $50 \mathrm{mg} / \mathrm{L}$ as Al. Al coagulation showed low removal efficiency towards positive $\mathrm{Cd}^{2+}$, and limited removal of other cationic ions as nickel and chrome by flocculation has also been reported before (Santinelli et al., 2012). Comparatively, Al coagulation showed significantly higher removal efficiency of phosphate, and residual phosphate was as low as 0.31 and $0.05 \mathrm{mg} / \mathrm{L}$ as $\mathrm{P}$ at $\mathrm{AlCl}_{3}$ doses of 3 and $5 \mathrm{mg} / \mathrm{L}$ as $\mathrm{Al}$, respectively. The remarkable removal of phosphate by $\mathrm{Al}$ coagulation has been reported before (Aguilar et al., 2002; Santinelli et al., 2012; Georgantas and Grigoropoulou, 2007), and the dominant interactions between alum and phosphates included the adsorption of phosphate onto $\mathrm{Al}(\mathrm{OH})_{3}$, the incorporation of phosphate onto stabilized colloids via sweep flocculation, and the formation of insoluble Al-P precipitates (Aguilar et al., 2002).

The introduction of fluoride showed critically different effects on $\mathrm{Al}$ coagulation regarding the removal of $\mathrm{Cd}$ and phosphate. Fluoride at low $R_{\mathrm{F}: \mathrm{Al}}$ of $1: 5$ and 1:1 showed a beneficial effect on the removal of $\mathrm{Cd}$, whereas at elevated $R_{\mathrm{F}: \mathrm{Al}}$, higher levels of residual Cd were observed. As for the removal of phosphate, fluoride at the $R_{F: A l}$ value of 10:1 contributed to a significant increase in residual phosphate over a wide $\mathrm{Al}$ dose range, from 0.5 to $10 \mathrm{mg} / \mathrm{L}$. At $R_{\mathrm{F}: \mathrm{Al}}$ values below 10:1, little effect of fluoride on residual phosphate was observed at sufficient $\mathrm{Al}$ doses, above $3 \mathrm{mg} / \mathrm{L}$. However, in insufficient $\mathrm{Al}$ dose ranges of 0.5 and $1 \mathrm{mg} / \mathrm{L}$ as $\mathrm{Al}$, fluoride at $R_{\mathrm{F}: A l}$ of above 1:1 inhibited the removal of phosphate and the levels of residual phosphate increased to a large extent.

In the absence of fluoride, the $\zeta$-potential of $\mathrm{Al}$ flocs in the Cd-removing system was consistently above $0 \mathrm{mV}$ with $\mathrm{Al}$
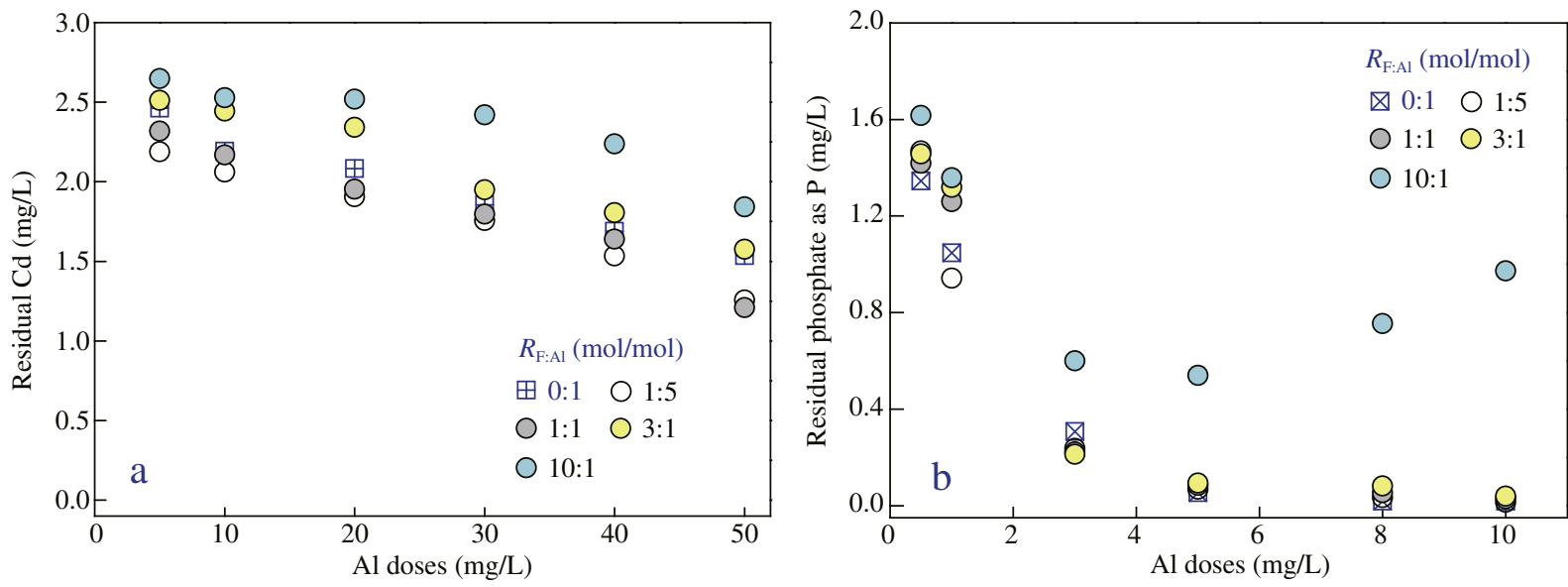

Fig. 1 - Effects of fluoride at $R_{\mathrm{F}: \mathrm{Al}}$ values on the removal of (a) Cd and (b) phosphate by $\mathrm{Al}$ coagulation with elevated $\mathrm{Al}$ doses. Conditions: $\mathrm{pH}=7.06,[\mathrm{Cd}]_{0}=3 \mathrm{mg} / \mathrm{L},[\text { phosphate }]_{0}=2 \mathrm{mg} / \mathrm{L}$ as $\mathrm{P}$. 
doses increasing from 5 to $50 \mathrm{mg} / \mathrm{L}$. The introduction of fluoride lowered the $\zeta$-potential of $\mathrm{Al}$ flocs, and a more significant decrease was observed either at higher fluoride levels or at lower $\mathrm{Al}$ doses (Fig. 2). The reversal of $\zeta$-potential to below $0 \mathrm{mV}$ occurred at high $R_{\mathrm{F}: \mathrm{Al}}$ of 3:1 at the relatively low $\mathrm{Al}$ dose of $5 \mathrm{mg} / \mathrm{L}$ as $\mathrm{Al}$. $\zeta$-Potential reversal was not observed at the elevated $\mathrm{Al}$ dose of $40 \mathrm{mg} / \mathrm{L}$. Generally, the absolute values of the $\zeta$-potential approached $0 \mathrm{mV}$ after introducing fluoride. In the phosphate-removing system, much lower $\zeta$-potential was observed even in the absence of fluoride (i.e., $R_{\mathrm{F}: \mathrm{Al}}=0: 1$ ), owing to the attachment and incorporation of negative phosphate ions within $\mathrm{Al}(\mathrm{OH})_{3}$ flocs. Fluoride at high $\mathrm{R}_{\mathrm{F}: \mathrm{Al}}$ of above 3:1 further decreased the $\zeta$-potential (Fig. 2). Comparatively, more significant decrease in $\zeta$-potential was observed in the Cd-removing system than in the phosphateremoving system (Fig. S3).

The adsorption of fluoride onto hydrous aluminum oxides via ligand exchange, as indicated by Eq. (1), cannot contribute to $\zeta$-potential reversal, although it did decrease the $\zeta$-potential to some extent (Pommerenk and Schafran, 2005). In this study, fluoride significantly lowered the $\zeta$-potential and the reversal of the $\zeta$-potential to negative values was observed. It was assumed that besides adsorbing onto the surfaces of $\mathrm{Al}(\mathrm{OH})_{3}$ precipitates, fluoride also participated in the hydrolysis of $\mathrm{Al}$ salts and in the formation of $\mathrm{Al}$ precipitates. Al-F complex formation was involved in the removal of fluoride by Al coagulation, and the formed flocs differed greatly from the $\mathrm{Al}(\mathrm{OH})_{3}$ flocs with adsorbed fluoride (Gong et al., 2012). The formed $\mathrm{Al}$ precipitates in these two systems were assumed to be significantly different from the $\mathrm{Al}(\mathrm{OH})_{3}$ precipitates.

$\equiv \mathrm{Al}-\mathrm{OH}+\mathrm{F}^{-} \rightarrow \equiv \mathrm{Al}-\mathrm{F}^{-}+\mathrm{OH}^{-}$

The removal of fluoride in these two systems was compared in terms of the adsorption density of fluoride $\left(Q_{F}\right.$, i.e., $\mathrm{mg}$ of removed fluoride per $\mathrm{mg}$ insoluble $\mathrm{Al}$ precipitates as $\mathrm{Al}$ ). $\mathrm{Q}_{\mathrm{F}}$ values increased with elevated $R_{\mathrm{F}: \mathrm{Al}}$ in both systems (Fig. S4), and the maximum $Q_{F}$ values were 4.7 and $3.0 \mathrm{mgF} / \mathrm{mgAl}$ in $\mathrm{Cd}$ and P-removing system, respectively. Phosphate inhibited the

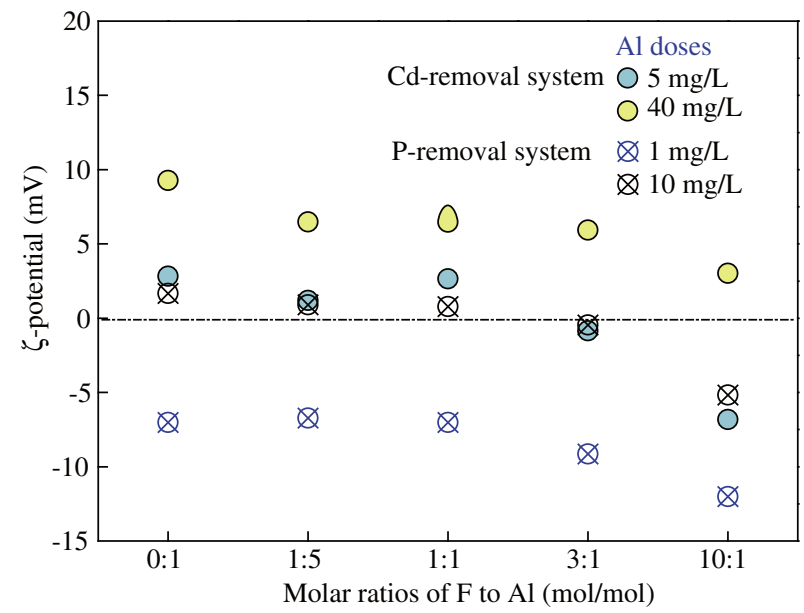

Fig. 2 - Effects of fluoride at different $R_{F: A l}$ values on $\zeta$-potential in the removal of (a) Cd and (b) phosphate by $\mathrm{Al}$ coagulation. Conditions: $\mathrm{pH}=7.06,[\mathrm{Cd}]_{0}=3 \mathrm{mg} / \mathrm{L}$, $[\text { phosphate }]_{0}=2 \mathrm{mg} / \mathrm{L}$ as $\mathrm{P}$. attachment of fluoride onto $\mathrm{Al}$ precipitates and the removal of total fluoride thereafter.

Fluoride also contributed to elevated levels of residual $\mathrm{Al}$ in both systems; the ratios of residual $\mathrm{Al}$ to total $\mathrm{Al}$, as indicated by $\mathrm{Al}_{\text {Res }} / \mathrm{Al}_{\text {Tot }}$, were observed to increase markedly with elevated $R_{\mathrm{F}: A l}$ values (Fig. 3). Without fluoride present, residual Al concentrations were consistently below $0.1 \mathrm{mg} / \mathrm{L}$ over a wide $\mathrm{Al}$ dose range. Elevated $R_{\mathrm{F}: \mathrm{Al}}$ favored the formation of soluble Al-F complexes and inhibited the hydrolysis and precipitation of Al salts thereafter. Al-F complex formation was dependent on $\mathrm{pH}$, and the ratios of complexed fluoride were above $99 \%$ at acidic $\mathrm{pH}<5$, whereas at $\mathrm{pH} 7.0, \mathrm{Al}-\mathrm{F}$ complexes tended to dissociate into free fluoride, and complexed fluoride was below the detection limit $\left(R_{\mathrm{F}: \mathrm{Al}}=\right.$ 0.53:1) (Gong et al., 2012). The elevation of $R_{\mathrm{F}: \mathrm{Al}}$ to above 2.13:1 enabled the formation of Al-F complexes at pH 7.0, whereas at $\mathrm{pH} 8.0$ their formation rarely occurred even at high $R_{\mathrm{F}: \mathrm{Al}}$ of 2.85:1 (Gong et al., 2012). In this study, extremely high $R_{\mathrm{F}: \mathrm{Al}}$ benefited Al-F complex formation and reduced the particulate $\mathrm{Al}$ available for the removal of $\mathrm{Cd}$ and phosphate. Comparatively, the negative phosphate ion inhibited Al fluoride interactions, and the effect of fluoride on residual $\mathrm{Al}$ was less significant than that in the Cd-removing system.

\subsection{Effects of fluoride on the removal of $\mathrm{Cd}$ and phosphate at different $p H$}

\subsubsection{Effects of fluoride on the removal of $\mathrm{Cd}$ at different $p \mathrm{H}$}

Fig. 4 indicates the effects of fluoride at different $R_{\mathrm{F}: \mathrm{Al}}$ on $\mathrm{Cd}$ removal, $\zeta$-potential, and $\Delta$ residual $\mathrm{Al}$ in $\mathrm{pH} 6$ to $8 . \Delta$ Residual $\mathrm{Al}$ was calculated by the subtraction of the residual $\mathrm{Al}$ concentration from that obtained in the absence of fluoride. In the absence of fluoride, i.e., $R_{\mathrm{F}: \mathrm{Al}}=0: 1$, Cd removal increased with elevated $\mathrm{pH}$, and the $\zeta$-potential approached $0 \mathrm{mV}$ accordingly. At pH 6 the removal of $\mathrm{Cd}$ was slight, and fluoride showed little effect; nevertheless a decreased $\zeta$-potential was observed. At elevated $\mathrm{pH} 7$ and 8, fluoride showed little effect at $R_{\mathrm{F}: \mathrm{Al}}<1: 1$, and further elevated $R_{\mathrm{F}: \mathrm{Al}}$ adversely inhibited Cd removal. At pH 8 a negative $\zeta$-potential was observed due to the introduction of fluoride. However, this effect did not favor the removal of positively-charged $\mathrm{Cd}$. The removal of $\mathrm{Cd}$ by $\mathrm{Al}$ coagulation was independent of $\zeta$-potential. It is inferred that the ligand exchange between surface hydroxyl groups and fluoride consumes available sites and inhibits $\mathrm{Cd}$ removal thereafter. $\Delta$ Residual $\mathrm{Al}$ increased with elevated $R_{\mathrm{F}: \mathrm{Al}}$ at $\mathrm{pH}$ 6, owing to the more significant formation of Al-F complexes (Eq. (2)). At elevated pH, the complexed fluoride (complexed-F) was insignificant, and residual Al was only slightly affected by fluoride even at high $\mathrm{R}_{\mathrm{F}: \mathrm{Al}}$ of 6:1.

$\mathrm{Al}^{3+}+n \mathrm{~F}^{-} \rightarrow \mathrm{Al}-\mathrm{F}_{n}$ complexes

2.2.2. Effects of fluoride on the removal of phosphate at different $p H$ Fig. 5 illustrates the effects of fluoride on the removal of phosphate, $\zeta$-potential, and $\Delta$ residual $\mathrm{Al}$ in $\mathrm{pH} 6$ to 8 . Fluoride at $R_{\mathrm{F}: \mathrm{Al}}=1: 5$ showed little effect on phosphate removal over a wide $\mathrm{pH}$ range. At elevated $\mathrm{R}_{\mathrm{F}: \mathrm{Al}}$ of above 1:1, phosphate removal was greatly inhibited at $\mathrm{pH}$ 6, and residual phosphate significantly increased from 0.14 to $1.78 \mathrm{mg} / \mathrm{L}$ at $R_{\mathrm{F}: \mathrm{Al}}=6: 1$. At pH 7 and 8, fluoride showed little effect on phosphate removal. 

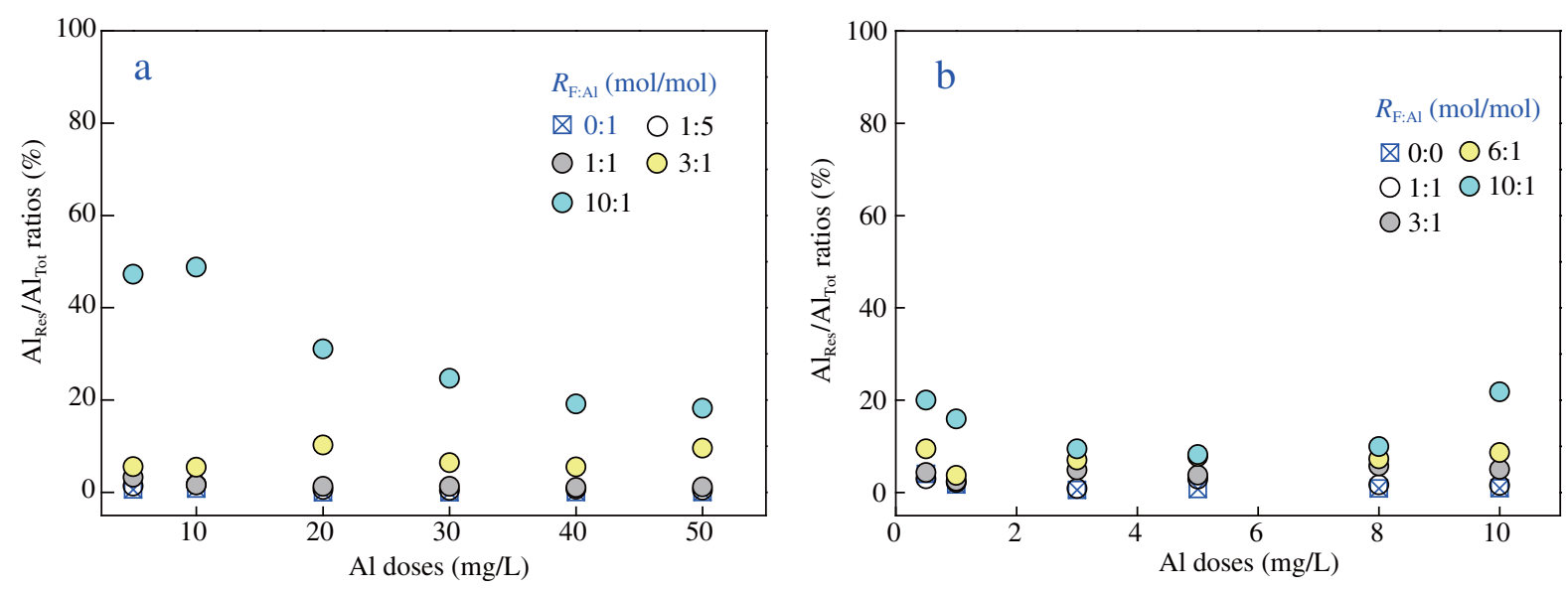

Fig. 3 - Effects of fluoride at different $R_{\mathrm{F}: \mathrm{Al}}$ values on residual $\mathrm{Al}$ in the removal of (a) $\mathrm{Cd}$ and (b) phosphate by $\mathrm{Al}$ coagulation. Conditions: $\mathrm{pH}=7.06,[\mathrm{Cd}]_{0}=3 \mathrm{mg} / \mathrm{L},[\text { phosphate }]_{0}=2 \mathrm{mg} / \mathrm{L}$ as $\mathrm{P}$.

Fluoride lowered the $\zeta$-potential of $\mathrm{Al}$ precipitates at $\mathrm{pH} 6-8$, and a more significant decrease was observed at elevated $R_{\mathrm{F}: A l}$. However, $\zeta$-potential was below $0 \mathrm{mV}$ even in the absence of fluoride, and the fact that fluoride lowers $\zeta$-potential played a limited role to inhibit phosphate removal. Additionally, it was observed that fluoride showed little effect on Al hydrolysis, and $\Delta$ residual Al showed little variation in $\mathrm{pH}$ 6-8 even at high $\mathrm{R}_{\mathrm{F}: \mathrm{Al}}$ of 6:1. Comparatively, in the Cd-removing system $\Delta$ residual Al increased remarkably with elevated $R_{\mathrm{F}: A l}$ at pH 6 (Fig. 4c). This was first attributed to the much higher $\mathrm{Al}$ dose, i.e., $30 \mathrm{mg} / \mathrm{L}$ as $\mathrm{Al}$, than that in the Cd-removing system $(3 \mathrm{mg} / \mathrm{L}$ as $\mathrm{Al})$. Additionally, in the phosphate-removing system, phosphate at $2 \mathrm{mg} / \mathrm{L}$ as $\mathrm{P}$ inhibited $\mathrm{Al}$ hydrolysis, and the adverse effect of fluoride towards Al hydrolysis was lowered accordingly. The stable $\Delta$ residual $\mathrm{Al}$ at different $\mathrm{R}_{\mathrm{F}: \mathrm{Al}}$ inferred the determining role of Al-F complex formation in the inhibition of phosphate removal at $\mathrm{pH}$ 6. At elevated $\mathrm{pH} 7$ and 8, the formation of $\mathrm{Al}-\mathrm{F}$ complexes was slight and little effect was observed thereafter.

\subsection{Al-F complex formation at different $p H$}

Fig. 6 illustrates the ratios of complexed-F to total fluoride in the treated water after removing particulate fluoride by $0.45-\mu \mathrm{m}$ membrane filtration. The ratios of complexed-F decreased with elevated $R_{\mathrm{F}: \mathrm{Al}}$ values, owing to less $\mathrm{Al}$ being available for Al-F complex formation. Additionally, the ratios of
complexed-F decreased with increasing $\mathrm{pH}$, and free fluoride was the dominant species at $\mathrm{pH}$ above 6 in both systems for the removal of $\mathrm{Cd}$ and phosphate. The dissociation of complexed- $F$ to free fluoride was ascribed to the strong competition of $\mathrm{OH}^{-}$ towards Al as high pH levels (Gong et al., 2012). Furthermore, phosphate inhibited Al-F complex formation, and the observed ratios of complexed-F were lower than those in the Cd-removing system. MINTEQ modeling indicated that the formation of $\mathrm{Al}^{-} \mathrm{PO}_{4}$ species (i.e., $\mathrm{Al}_{2} \mathrm{PO}_{4}^{3+}, \mathrm{AlHPO}+$ ) did occur; however, the ratio was as low as below $4.5 \%$ (Fig. S5). The consumption of $\mathrm{Al}$ salts by phosphate was negligible. The lower complexed-F ratios in the P-removing system were attributed to the inhibition of the Al fluoride interaction by phosphate.

\subsection{Proposed dominant Al fluoride interactions at different $\mathrm{pH}$ and $R_{F: A l}$}

The effects of fluoride on the removal of Cd and phosphate by $\mathrm{Al}$ coagulation were dependent on the species distribution of $\mathrm{Al}$ and fluoride, $\mathrm{R}_{\mathrm{F}: \mathrm{Al}}$, and the interactions among these species. The species distribution of $\mathrm{Al}$ and $\mathrm{F}$ and the main reactions over wide equilibrium $\mathrm{pH}$ and $\mathrm{R}_{\mathrm{F}: \mathrm{Al}}$ ranges are illustrated in Fig. 7.

Before being dosed, the species distribution of $\mathrm{Al}$ and $\mathrm{F}$ in the mixed solution was mainly dependent on $\mathrm{R}_{\mathrm{F}: \mathrm{Al}}$, and free fluoride existed at $\mathrm{R}_{\mathrm{F}: \mathrm{Al}}>1$ whereas free $\mathrm{Al}$ was present at
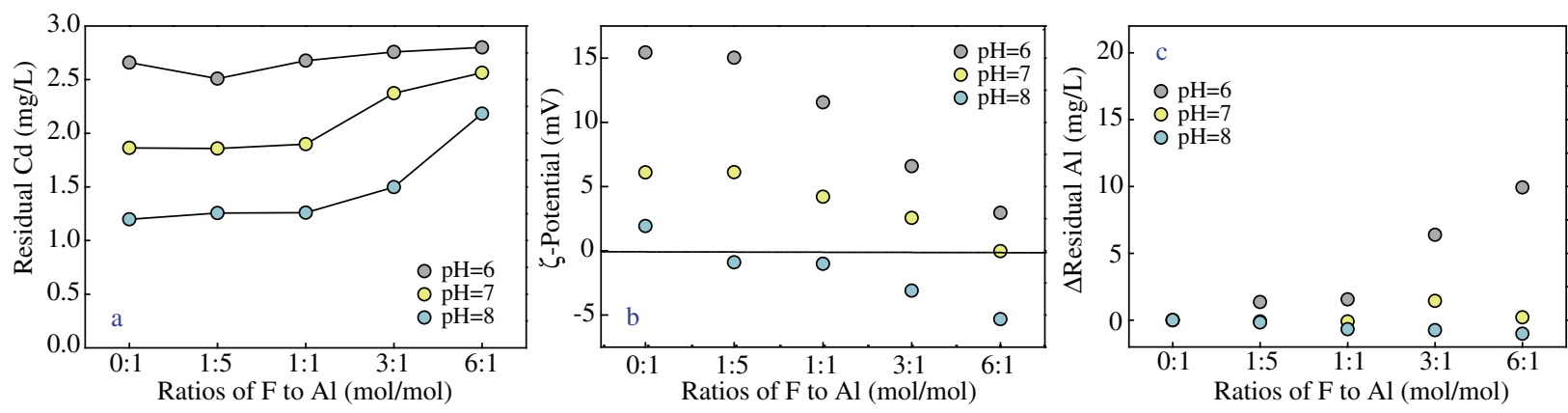

Fig. 4 - Effects of fluoride at different $R_{\mathrm{F}: \mathrm{Al}}$ on Cd removal, $\zeta$-potential, and $\Delta$ residual $\mathrm{Al}$ over a wide pH range from 4 to 8 in Cd-removing system at $\mathrm{Al}$ dose of $30 \mathrm{mg} / \mathrm{L}$ as $\mathrm{Al}$. 

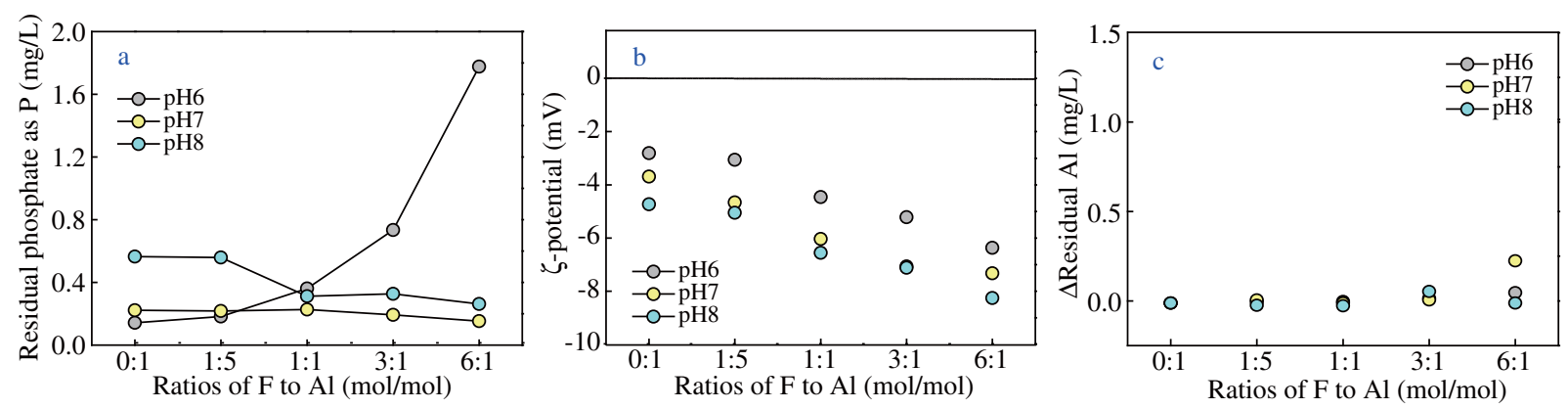

Fig. 5 - Effects of fluoride at different $R_{\mathrm{F}: \mathrm{Al}}$ on phosphate removal, $\zeta$-potential, and $\Delta$ residual $\mathrm{Al}$ over a wide $\mathrm{pH}$ range from 4 to 8 in phosphate-removing system at $\mathrm{Al}$ dose of $3 \mathrm{mg} / \mathrm{L}$ as $\mathrm{Al}$.

$R_{\mathrm{F}: \mathrm{Al}}<1$ (Fig. 7a). $\mathrm{pH}$ also played a role, and the dissolution of Al-F complexes to free $\mathrm{F}^{-}$occurred at high $\mathrm{R}_{\mathrm{F}: \mathrm{Al}}$ owing to the elevated $\mathrm{pH}$ (Fig. S1).

After being dosed, the equilibrium $\mathrm{pH}$ impacted the main reactions involved and the species distribution of $\mathrm{Al}$ and $\mathrm{F}$ thereafter (Fig. 7b). In the case with free $A l$ present $\left(R_{F: A l}<1\right)$, the hydrolysis and polymerization of $\mathrm{Al}^{3+}$ occurred at $\mathrm{pH}$ above 4 (Georgantas and Grigoropoulou, 2007) (Eqs. (3)-(4)), and the ratios of each $\mathrm{Al}$ polymer with different extent of polymerization $\left(\mathrm{Al}_{3}-\mathrm{Al}_{21}\right)$ were highly dependent on $\mathrm{pH}$ (Zhao et al., 2009). $\mathrm{Al}^{3+}$ and the hydrolyzed $\mathrm{Al}(\mathrm{III})$ species tend to form Al-F complexes at acidic pH (Eqs. (2) and (5)), which can be rapidly achieved within several seconds (Plankey et al., 1988). At $\mathrm{pH}>5, \mathrm{Al}-\mathrm{F}$ complexes dissociated into free fluoride (Eq. (6)), owing to the competition of $\mathrm{OH}^{-}$towards $\mathrm{Al}$ (Gong et al., 2012). Additionally, Al-F complexes may directly react with $\mathrm{OH}^{-}$and form insoluble $\operatorname{AlF}_{\mathrm{m}}(\mathrm{OH})_{\mathrm{n}}$ precipitates (Eq. (7)), and free $\mathrm{F}^{-}$and Al-F complexes can also adsorb onto $\mathrm{Al}(\mathrm{OH})_{3}$ precipitates (Eqs. (8)-(9)). These two effects contributed to the transformation of free fluoride to insoluble fluoride, and the removal of total fluoride thereafter (Fig. S6). At elevated $\mathrm{pH}$, the dissolution of insoluble $\mathrm{Al}(\mathrm{OH})_{3}, \mathrm{AlF}_{\mathrm{m}}(\mathrm{OH})_{\mathrm{n}}$, and $\mathrm{Al}(\mathrm{OH})_{\mathrm{n}} \mathrm{F}_{\mathrm{m}}$ into soluble $\mathrm{Al}$ species occurred (Eqs. (10)-(12)), and the levels of free fluoride and soluble $\mathrm{Al}$ increased accordingly. The species distribution of fluoride and $\mathrm{Al}$ in different $\mathrm{pH}$ and $\mathrm{R}_{\mathrm{F}: \mathrm{Al}}$ ranges is illustrated in Fig. 7c. It was noted that the formation of $\mathrm{CdF}^{+}$complexes and $\mathrm{Al}-\mathrm{PO}_{4}$ species did occur; however, these reactions were ignored due to their low ratios (Figs. S5 and S7).

$\mathrm{Al}^{3+}+n \mathrm{OH}^{-} \rightarrow \mathrm{Al}(\mathrm{OH})_{n}^{(3-n)+}$

$n \mathrm{Al}^{3+} \stackrel{\mathrm{OH}^{-}}{\rightarrow} \mathrm{Al}_{n}^{m+}$

$\mathrm{Al}(\mathrm{OH})_{n}{ }^{(3-n)+}+m \mathrm{~F}^{-} \rightarrow \mathrm{Al}(\mathrm{OH})_{n} \mathrm{~F}_{m}$

$\mathrm{Al}-\mathrm{F}_{n}$ complexes $\rightarrow \mathrm{Al}-\mathrm{F}_{n-m}$ complexes $+m \mathrm{~F}^{-}$

$\mathrm{Al}-\mathrm{F}_{m+p}$ complexes $+n \mathrm{OH}^{-} \rightarrow \mathrm{Al}-\mathrm{F}_{m}(\mathrm{OH})_{n}$ complexes $+p \mathrm{~F}^{-}$

$\mathrm{Al}(\mathrm{OH})_{3}+n \mathrm{~F}^{-} \rightarrow \mathrm{Al}(\mathrm{OH})_{3} \mathrm{~F}_{n}$

Al- $\mathrm{F}_{p}$ complexes $+n \mathrm{Al}(\mathrm{OH})_{3} \rightarrow \mathrm{Al}_{n+1}(\mathrm{OH})_{3 n} \mathrm{~F}_{p}$

$\mathrm{Al}(\mathrm{OH})_{3}+\mathrm{OH}^{-} \rightarrow \mathrm{AlO}_{2}^{-}+2 \mathrm{H}_{2} \mathrm{O}$

$\mathrm{AlF}_{m}(\mathrm{OH})_{n} \stackrel{\mathrm{OH}^{-}}{\rightarrow}$ soluble $\mathrm{Al}+m \mathrm{~F}^{-}+\mathrm{H}_{2} \mathrm{O}$

$\mathrm{Al}(\mathrm{OH})_{n} \mathrm{~F}_{m} \stackrel{\mathrm{OH}^{-}}{\rightarrow}$ solubleAl $+m \mathrm{~F}^{-}+\mathrm{H}_{2} \mathrm{O}$

The Al-fluoride interactions and their species distribution contributed to the observed varying trends of $\zeta$-potential and
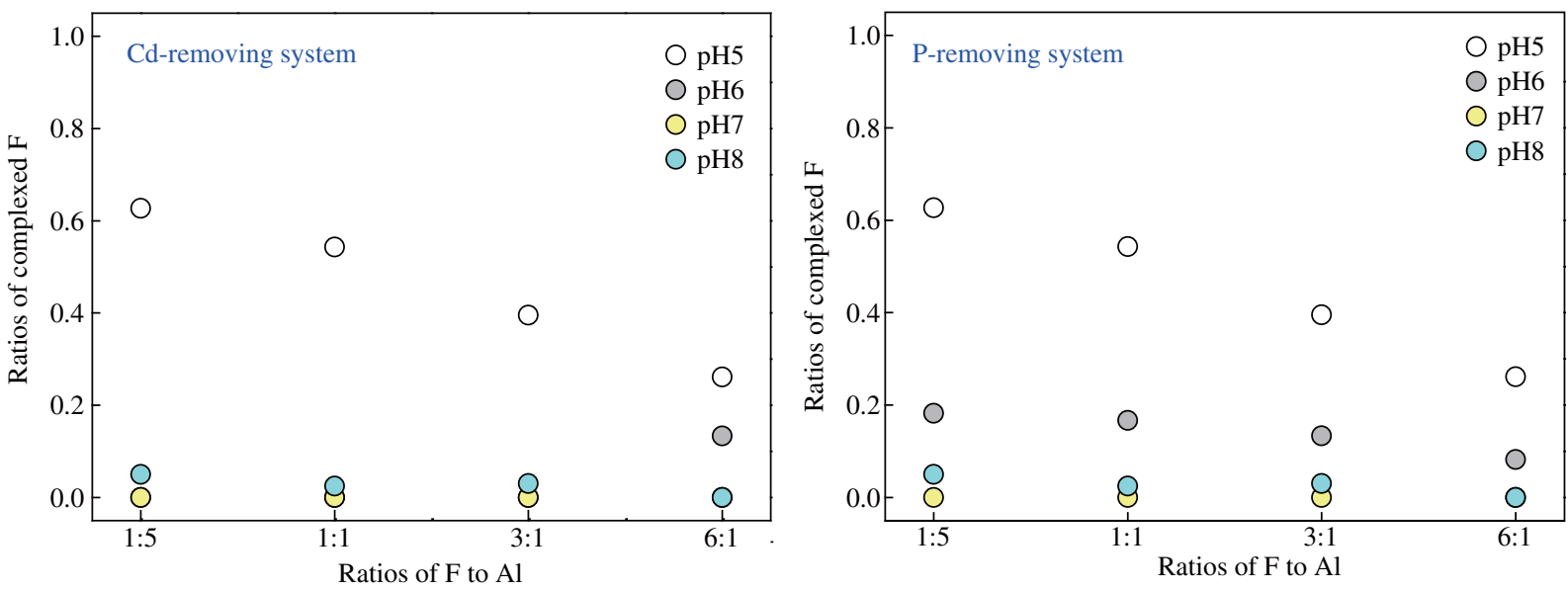

Fig. 6 - Ratios of complexed-F to total fluoride over a wide pH range from 4 to 8 in (a) Cd-removing system and (b) phosphate-removing system at $\mathrm{Al}$ dose $=3 \mathrm{mg} / \mathrm{L}$ as $\mathrm{Al}$. 
a Dominant species in mixed solution of $\mathrm{AlCl}_{3}$ and $\mathrm{NaF}$ prior to dosing

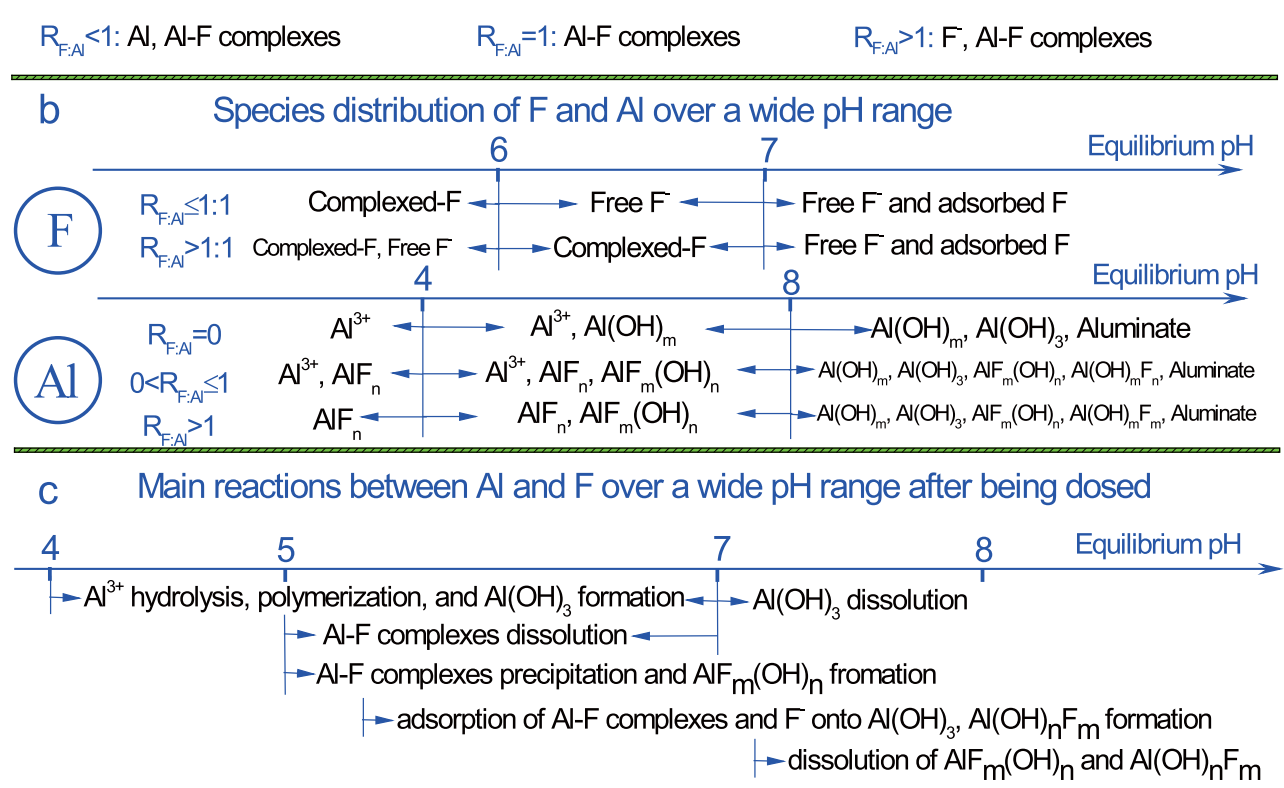

Fig. 7 - Proposed main species distribution and transformation of $\mathrm{Al}$ and $\mathrm{F}$ over wide equilibrium $\mathrm{pH}$ and $\mathrm{R}_{\mathrm{F}: \mathrm{Al}}$ ranges. a: Dominant species of $\mathrm{Al}$ and $\mathrm{F}$ in the mixed solution of $\mathrm{AlCl}_{3}$ and $\mathrm{NaF}$ prior to dosing; $\mathrm{b}$ : species distribution of $\mathrm{F}$ and $\mathrm{Al}$; c: main reactions between $\mathrm{Al}$ and $\mathrm{F}$ over a wide $\mathrm{pH}$ rang after being dosed.

residual $\mathrm{Al}$, and the effect of fluoride on the removal of $\mathrm{Cd}$ and phosphate by $\mathrm{Al}$ coagulation was highly dependent on $\mathrm{pH}$ and $R_{\mathrm{F}: A l}$ (Table S2). Briefly, the removal of neither $\mathrm{Cd}$ nor phosphate was affected by fluoride at $R_{\mathrm{F}: \mathrm{Al}}$ of below 1:1 in a wide $\mathrm{pH}$ range; however, fluoride at $R_{\mathrm{F}: \mathrm{Al}}>3: 1$ showed significant adverse effects on their removal. Additionally, the inhibitive effect of fluoride was $\mathrm{pH}$ dependent, and its remarkable inhibition of Cd removal was observed in neutral and basic $\mathrm{pH}$ of 7 and 8, whereas that on phosphate removal was prominent in weakly acidic $\mathrm{pH}$ of 5 and 6 .

The $\mathrm{Cd}$ ion rarely participates in $\mathrm{Al}$ hydrolysis, and its removal may be mainly achieved by the formation of outer-sphere complexes between $\mathrm{Cd}$ and the hydroxyl groups on the surfaces of $\mathrm{Al}(\mathrm{OH})_{3}, \operatorname{AlF}_{m}(\mathrm{OH})_{n}$, and $\mathrm{Al}(\mathrm{OH})_{n} \mathrm{~F}_{m}$. The oxygen on adsorbent surfaces was reported to be a strong Lewis base and tended to form complexes with $\mathrm{Cd}$ (II) ions as electron acceptors (Cooper et al., 2002). As for phosphate, the formation of insoluble $\mathrm{Al}-\mathrm{PO}_{4}$ precipitates such as $\mathrm{Al}_{2} \mathrm{PO}_{4}^{3+}$ and $\mathrm{AlHPO}+$ may play a role; however, this effect is relatively low. The removal of phosphate may be mainly attributed to its incorporation into stabilized colloids via sweep flocculation and to its attachment onto the surfaces of $\mathrm{Al}(\mathrm{OH})_{3}, \mathrm{AlF}_{m}(\mathrm{OH})_{n}$, and $\mathrm{Al}(\mathrm{OH})_{n} \mathrm{~F}_{m}$. Besides this, other mechanisms such as electrostatic attraction, ionic exchange, and surface microprecipitation may also be involved in their removal, and further studies are required to elucidate the mechanisms.

\section{Conclusions}

Fluoride adversely affects the removal of both Cd and phosphate by $\mathrm{Al}$ coagulation, and the extent of this effect is highly dependent on $\mathrm{pH}$ and $\mathrm{R}_{\mathrm{F}: \mathrm{Al}}$. Fluoride shows an inhibitive effect on the removal of $\mathrm{Cd}$ at $R_{\mathrm{F}: \mathrm{Al}} \geq 3: 1$, whereas at low $R_{\mathrm{F}: \mathrm{Al}}$ a slight beneficial effect is interestingly observed. The removal of phosphate decreases at either high levels of fluoride $\left(R_{\mathrm{F}: \mathrm{Al}}=\right.$ 10:1) or insufficient $\mathrm{Al}$ doses of below $2 \mathrm{mg} / \mathrm{L}$ as $\mathrm{Al}$. Fluoride inhibits rather than improves $\mathrm{Cd}$ removal over a wide $\mathrm{pH}$ range, although it does lower $\zeta$-potential. Fluoride inhibits the removal of phosphate at the acidic $\mathrm{pH} 6$, and the formation of Al-F complexes plays an important role. At pH 7 to 8, fluoride shows little effect on phosphate removal due to the dissociation of Al-F complexes into free $\mathrm{F}^{-}$. Moreover, phosphate inhibits $\mathrm{Al}-\mathrm{F}$ complex formation and the removal of total fluoride. This study promotes the understanding of the removal of heavy metals and phosphate by $\mathrm{Al}$ coagulation in the simultaneous presence of fluoride. Besides this, this study also indicates the feasibility of using the spent in-situ $\mathrm{Al}_{2} \mathrm{O}_{3} \cdot \mathrm{xH}_{2} \mathrm{O}$ with adsorbed fluoride, after its being dissolved by acid solution, for the removal of $\mathrm{Cd}$ and phosphate. As for the spent in-situ $\mathrm{Al}_{2} \mathrm{O}_{3} \cdot \mathrm{xH}_{2} \mathrm{O}$ with adsorbed fluoride obtained from real treatment plants, the $R_{\mathrm{F}: \mathrm{Al}}$ is critically low at below 0.1:1, and the adverse effect of fluoride is slight.

\section{Acknowledgments}

This work was supported by the National Natural Science Foundation of China (Nos. 21177143, 21177144) and the key project of the National "863" High-Tech R\&D Program of China (No. 2012AA062604). Moreover, the author Ruiping Liu gratefully acknowledges the support of the Beijing Nova Program (No. 2013054).

\section{Appendix A. Supplementary data}

Supplementary data to this article can be found online at http://dx.doi.org/10.1016/j.jes.2014.10.024. 


\section{R E F E R E N C E S}

Aguilar, M.I., Sáez, J., Lloréns, M., Soler, A., Ortuño, J.F., 2002. Nutrient removal and sludge production in the coagulation-flocculation process. Water Res 36 (11), 2910-2919.

Akbal, F., Camcl, S., 2010. Comparison of electrocoagulation and chemical coagulation for heavy metal removal. Chem Eng Technol 33 (10), 1655-1664.

Bhatnagar, A., Kumar, E., Sillanpää, M., 2011. Fluoride removal from water by adsorption-a review. Chem Eng J 171 (3), 811-840.

Cooper, C., Jiang, J.Q., Ouki, S., 2002. Preliminary evaluation of polymeric Fe- and Al-modified clays as adsorbents for heavy metal removal in water treatment. J Chem Technol Biotechnol 77 (5), 546-551.

Corbillon, M.S., Olazabal, M.A., Madariaga, J.M., 2008. Potentiometric study of aluminium-fluoride complexation equilibria and definition of the thermodynamic model. J. Solut. Chem. 37 (4), 567-579.

Driscoll, C.T., Baker, J.P., Bisogni, J.J., Schofield, C.L., 1980. Effect of aluminium speciation on fish in dilute acidified waters. Nature 284 (5752), 161-164.

Fawell, J., Bailey, K., Chilton, J., Dahi, E., Fewtrell, L., Magara, Y., 2006. Fluoride in Drinking-water. IWA Publishing, London.

Georgantas, D.A., Grigoropoulou, H.P., 2007. Orthophosphate and metaphosphate ion removal from aqueous solution using alum and aluminum hydroxide. J. Colloid Interface Sci. 315 (1), 70-79.

Gong, W.X., Qu, J.H., Liu, R.P., Lan, H.C., 2012. Effect of aluminum fluoride complexation on fluoride removal by coagulation. Colloids Surf. A 395, 88-93.

Liu, R.P., Gong, W.X., Lan, H.C., Gao, Y.P., Liu, H.J., Qu, J.H., 2011. Defluoridation by freshly prepared aluminum hydroxides. Chem Eng J 175, 144-149.

Liu, R.P., Zhu, L.J., Gong, W.X., Lan, H.C., Liu, H.J., Qu, J.H., 2013. Effects of fluoride on coagulation performance of aluminum chloride towards Kaolin suspension. Colloids Surf. A 421, 84-90.

Meng, X.G., Bang, S., Korfiatis, G.P., 2000. Effects of silicate, sulfate, and carbonate on arsenic removal by ferric chloride. Water Res 34 (4), 1255-1261.
Merzouk, B., Gourich, B., Sekki, A., Madani, K., Chibane, M., 2009. Removal turbidity and separation of heavy metals using electrocoagulation-electroflotation technique: a case study. J Hazard Mater 164 (1), 215-222.

Mohapatra, M., Anand, S., Mishra, B.K., Giles, D.E., Singh, P., 2009. Review of fluoride removal from drinking water. J. Environ. Manag. 91 (1), 67-77.

Neal, C., 1995. Aluminium speciation variations in an acidic upland stream draining the Hafren spruce forest, Plynlimon, Mid-Wales. J Hydrol 164 (1-4), 39-51.

Plankey, B.J., Patterson, H.H., Cronan, C.S., 1988. Kinetics of aluminum fluoride complexation in acidic waters. Environ Sci Technol 20 (2), 160-165.

Pommerenk, P., Schafran, G.C., 2005. Adsorption of inorganic and organic ligands onto hydrous aluminum oxide: evaluation of surface charge and the impacts on particle and NOM removal during water treatment. Environ Sci Technol 39 (17), 6429-6434.

Radic, N., Bralic, M., 1995. Aluminium fluoride complexation and its ecological importance in the aquatic environment. Sci Total Environ 172 (2-3), 237-243.

Santinelli, M., Eusebi, A.L., Fatone, F., Carniani, E., Battistoni, P., 2012. Processes comparison for nickel and chrome removal from urban landfill leachate. Desalin Water Treat 50 (1-3), 132-139.

Wen, R.M., Du, G.D., 2001. Methods and equipment for waste gases and water abatement during semiconductor materials and devices fabrication. Eng Sci 3 (2), 71-78.

Zhang, X.H., Xu, L.W., Zeng, Q.F., Zhu, Y.N., 2006. Acid fluoride-containing wastewater treatment project in rare earths refinery. China Water Wastewater 22 (8), 35-37.

Zhao, H., Liu, H.J., Qu, J.H., 2009. Effect of pH on the aluminum salts hydrolysis during coagulation process: formation and decomposition of polymeric aluminum species. J. Colloid Interface Sci. 330 (1), 105-112.

Zhu, Y.N., Xu, L.W., Zhang, X.H., Wang, D.Q., 2005. Treatment of acidic fluoride-containing wastewater in tantalum and niobium refinery. Chin. J. Rare Metals 29 (3), 325-327. 